\title{
Global governance: present and future
}

\author{
Jinseop Jang ${ }^{1}$, Jason McSparren ${ }^{1}$ and Yuliya Rashchupkina ${ }^{1}$
}

\begin{abstract}
Globalization, the end of the Cold War and increased involvement of non-state actors in global affairs represent fundamentally shifting relations of power, speeding up national economies' integration and contributing to the convergence of policies in different issue domains. This review considers the state of global governance by presenting a variety of global governance arrangements, key challenges facing governance in an increasingly globalized context and possibilities for the future governance. Current global governance arrangements favour flexibility over rigidity, prefer voluntary measures to binding rules and privilege partnerships over individual actions. This synopsis of the state of global governance examines the evolving role that sovereignty and the enduring human struggles for power and equity are playing in shaping international relations and governance. This contribution argues that individual empowerment, increasing awareness of human security, institutional complexity, international power shifts and the liberal world political paradigm will define the future of global governance. This article is published as part of a thematic collection dedicated to global governance.
\end{abstract}

\section{Introduction}

lobal governance is a product of neo-liberal paradigm shifts in international political and economic relations. The privileging of capital and market mechanisms over state authority created governance gaps that have encouraged actors from private and civil society sectors to assume authoritative roles previously considered the purview of the State. This reinforces the divergence of views about how to define the concept of global governance, issues that are of the utmost importance and priority. Some scholars argue that global governance as it is practiced is not working (Coen and Pegram, 2015: 417), while others believe that global governance is constantly adapting by readjusting strategies and approaches to solutions and developing new tools and measures to deal with issues that impact communities throughout the world (Held and Hale, 2011). Rather than judging current global governance, this contribution seeks to provide an overview of the current state of global governance by discussing its present state vis à vis the challenges that it faces and its future.

The perspective employed here presents global governance as a tool to identify solutions to problems created by neo-liberal globalization (Biermann and Pattberg, 2008: 279). As such, the concept of global governance relates to the interaction of myriad collective or individual entities emanating from various societal and professional orientations, which form networks that engage to address issues that threaten local and global communities. Global governance is concerned with issues that have become too complex for a single state to address alone. Humanitarian crises, military conflicts between and within states, climate change and

\footnotetext{
${ }^{1}$ University of Massachusetts Boston, Boston, USA
} 
economic volatility pose serious threats to human security in all societies; therefore, a variety of actors and expertise is necessary to properly frame threats, devise pertinent policy, implement effectively and evaluate results accurately to alleviate such threats.

\section{Structure and actors: stakeholders of global governance}

The proliferation of networked global markets, revolution in global communications technologies, the end of the Cold War and increased involvement of non-state actors in global affairs all contribute to "globalization". Increased interconnection among nations has advanced the exchange of knowledge by bringing peoples, cultures, communities and states closer in an era in which issues call for increased international collaboration (Bhagwati, 2004; McGrew, 2008). The scope of modern issues has become "global", beyond the capacity for state governments alone to address such issues. The former United Nations (UN) Secretary-General, Kofi Annan acknowledged that "no State, however powerful, can protect itself on its own" (Annan, 2005: 7) and that "the threats we face are interconnected" (Annan, 2005: 25). As a result, we witness broad strands of cooperative and competitive interdependency among sovereign nations, transnational corporations (TNCs), networks of experts and civil societies.

The current phenomenon of global governance is well captured by Biermann and Pattberg in their overview of global environmental governance for the Annual Review of Environmental Resources of 2008. They describe contemporary governance through the following features: (1) the emergence of new types of agency and of actors in addition to national governments; (2) the emergence of new mechanisms and institutions of global governance that go beyond traditional forms of state-led, treatybased regimes; and (3) increasing segmentation and fragmentation of the overall governance system across levels and functional spheres (Biermann and Pattberg, 2008: 280).

A multitude of actors define and shape the current structure of global governance. States, international organizations, nongovernmental organizations (NGOs), multinational corporations, scientific experts, civil society groups, networks, partnerships, private military and security companies, as well as transnational criminal and drug-trafficking networks provide world politics with multi-actor perspectives and take part in steering the political system (Dingwerth and Pattberg, 2006; Biermann and Pattberg, 2012; Karns and Mingst, 2015). Global governance actors broaden the scope of activities in which they are involved and they also change the patterns of interaction and cooperation in tackling current issues on a global level. Current global governance arrangements favour flexibility over rigidity, prefer voluntary measures to binding rules, choose partnerships over individual actions, and give rise to new initiatives and ideas.

While the modes of global governance vary widely, four general structures can be identified: International Governmental Organizations (IGOs), Public-Private Partnerships (PPPs), Private governance and tripartite governance mechanisms. IGOs such as the World Trade Organization and the UN system are examples of existing state-centered governance mechanisms. IGOs, however, utilize partnerships with non-state actors that have expertise and resources concentrated in service sectors and environments that IGOs may lack. Such arrangements maximize efficiency. Abbott and Snidal (2010) use the term "Transnational New Governance" to recognize the way IGOs expand capacity and access to resources by including private and nongovernmental actors and institutions. This formulates global collaborative networks in which IGOs shape and support the operations of NGOs and certain private enterprises. Such governance structures are considered to be PPPs. The UN Sustainable Development Goals (SDGs) utilize the PPP strategy across all aspects of implementation of the SDGs.

The UN Global Compact is another example of an international PPP. The UN Global Compact is a forum that encourages TNCs to share case studies that illustrate the ways a firm is implementing the SDGs in host communities where they operate. The objective is to formulate a digital record of best practices in Corporate Social Responsibility for public, private and civil society stakeholders located at all levels of governance-the local, state and transnational-to engage in discourse and form collaborative efforts for the purpose of accomplishing what the SDGs identify as expected outcomes. In addition, an increasing trend of private governance exists that sets sector-specific standards; and, there are alternative forms of governance that are considered as tripartite arrangements among state, private and civil society actors. Tripartite arrangements among state, private and civil society actors exemplify alternative, publicprivate or private governance arrangements. Tripartite governance such as the Extractive Industries Transparency Initiative, Publish What You Pay and the African Peer Review Mechanism, while categorized as PPPs, "are located in the policy space between states and markets" (Carbonnier et al., 2011: 250). PPPtype arrangements empower civil society actors to not only coordinate with state and corporate entities, but also to monitor state-corporate activities. Often such mechanisms are "voluntary, horizontal, multi-actor and participatory, and address global issues" (Ibid.).

In some areas of business, private governance has supplanted state authority to regulate industry, showcasing the work of private governance. Examples of private governance include international accounting standards; the private bond-rating agencies (for example, Moody's Investors Service and Standard and Poor's Rating Groups); International Chamber of Commerce rules and actions; private industry governance such as the Worldwide Responsible Apparel Manufacturing Principles and the Forest Stewardship Council (Karns and Mingst, 2015: 34); Equator Principles (Wright and Rwabizambuga, 2006). Global corporations also actively develop, promote and implement their own codes of conduct that concern issues of labour, environment and health. Those voluntary codes are usually adopted as a response to NGO campaigns, and primarily target developed country consumers, rather than tackle the problems faced by a diverse set of vulnerable worker groups. However, the processes through which codes have been developed enables better representation of hitherto excluded groups of workers (women export workers, homeworkers, casual workers) in social policy and labour regulation debates (Pearson and Seyfang, 2001).

Multi-actor configurations in global governance broaden the scope of policy solutions that, combined with current capacities for information sharing and learning, advance policy changes. Yet this also increases fragmentation and segmentation of different layers and clusters of rule-making and rule-implementing (Biermann and Pattberg, 2008: 289). The result is increased competition over resources that may lead to paralysis in cooperative efforts. On the other hand, this competition may produce innovative solutions. In the subsequent sections, we offer an overview of the current challenges to global governance concluding with a discussion on the role that it may play in the future.

\section{Present challenges of global governance}

A growing number of emerging global governance actors aim to contribute to the solution of interdependent issues supplementing, and sometimes clashing, with already established regimes 
designed to address certain international problems separately from other issues. Hale et al. (2013) define the situation when current international institutions fail to provide a coordinated response to current agendas challenges as "gridlock". Through the examples of sovereignty, and by discussing the questions of power and equality we will show how new developments in international relations affect and reshape collaborative responses to the most pressing issues.

Various global governance actors coalesce around the ideas and norms of human rights and human security; however, the principle of sovereignty continues to challenge the practical application of those ideas internationally. Huge and severe violations of peoples' rights and freedoms during inter- or intrastate wars or conflicts continue to erode human security in different parts of the world. However, governance actors working for the maintenance of peace, security, justice and the protection of human rights have limited capacity to improve situations because of complicated approval procedures of humanitarian intervention or authorization of peacekeeping operations. For example, political divisions and partisan interests within the Security Council (particularly the use of veto power by some of its permanent members) blocked any international response to the mass atrocities committed in Syria, thus strengthening impunity and encouraging the expansion of war crimes and crimes against humanity (Adams, 2015). A rise of nationalist sentiments and movements in Russia and some European countries also continues to erode international cooperation in response to challenges such as the huge influx of refugees, and the ongoing conflict in Ukraine. All of these threaten the international security, and order in general, that was created during the post-Cold War period. Yet, even as the principle of the responsibility to protect has gained political support and international legitimacy since it was introduced about a decade ago, its contribution to preventing mass atrocities and protection population remains low. As Luck (2015) points out, policy practitioners and scholars need to think in a more nuanced way about sovereignty. Both decisionmaking sovereignty, when governments choose to independently determine whether a particular course of action for the cause of human rights protection is in their national interest and erosion of sovereignty open the door to more atrocities within and across states' boundaries. This scholar, for instance, argues that the ineffective exercise of sovereignty by a number of states over their own territory becomes a significant barrier to exercising protection responsibilities in other places (Luck, 2015: 504).

Power in the current system of global governance has become more diffused. The power shift accompanying the rise of Brazil, Russia, India, China (the BRICs) and other so-called "rising powers" pose questions about the possible reordering or shifts in the current state of global governance. While advocating for better representation in institutions such as the International Monetary Fund, the World Bank and the UN Security Council, the governments of China, India, Brazil and other emerging economies have started to develop and maintain alternative institutions for economic and political collaboration. The Asian Infrastructure Investment Bank and the New Development Bank are products of these efforts. While rising powers' behaviours are shaped by the structural features of global capitalism, "the differing contours of BRICs' state-society relations provide the foundations for conflicts with Western powers over the most liberal aspects of global governance" (Stephen, 2014). The Western ideas of privatization, autonomous markets and open capital accounts are challenged by state-controlled approaches to development in the countries of so-called Global South. The proliferation of Sovereign Wealth Funds (SWFs), and national development banks in BRICs challenge an autonomous status of private capital in current global economic affairs. Those developments have led to the conclusion, by some scholars, that the most liberal features of global governance order are being contested by rising powers (Stephen, 2014). In addition, a small group of big and influential countries such as India and China gain more negotiating power (Barkin, 2013), as their nonparticipation in international treaties and policies (for example, climate change) might substantially diminish the effects of other countries' efforts to solve these global issues. The shifting global power configuration challenges each type of multilateral setting whether it concerns international institutions that have a selective Western-based membership (for example, OECD, NATO, G7/ G8); international institutions that shape the state of international policies but do not provide rising powers with equal membership and power in their governing bodies (the International Monetary Fund, the World Bank, the UN Security Council); or multilateral settings in which rising and established powers interact more or less on an equal footing (the World Trade Organization, the UN Framework Convention on Climate Change) (Lesage and Van De Graaf, 2015).

Economic and political inequality have long-lasting implications for governance both within and between states. Inequality in either form contributes to a rise in extremism and social unrest, and it also raises the questions of what responsibility the international community should bear for human development beyond just satisfying basic needs, that is, security, food and shelter. While the SDGs agenda of 2015 prioritizes the goal to "(e) nd poverty in all its forms everywhere" (United Nations, 2015), questions still remain about exactly who will fund this eradication of poverty and which actions are best suited to this fight. Global governance actors, for example, focus more on intervention measures in poor countries, as they are primarily guided by a "narrow" understanding of security rather than thinking of more long-term development issues, or the "everyday" insecurities experienced by individuals in different parts of the world. A huge diversification of financial sources of development aid complicates the task of applying a common framework, based on individuals' needs and development interests approach. In addition, the supply of development resources including official development assistance is also moving away from the old North towards the BRICs and other new official donors such as South Korea and Turkey, plus private foundations like the Bill and Melinda Gates Foundation, faith-based organizations, remittances from diasporas, heterogeneous SWFs and a plethora of Exchange-Traded Funds as well as novel sources of finance such as taxes on carbon, emissions, financial transactions and so forth (Shaw, 2015).

Thus, the observed changes in socio-economic and political aspects of the current world pose new questions and create new challenges for previously active participants of global policy processes, as well as for new actors of global governance. Global governance actors will need to critically reflect on the relevance of earlier policy tools to rapidly changing conditions in the current world.

\section{The future of global governance}

Global governance is arguably inevitable for the survival of the human race in present and future generations. Although global governance sometimes appears fragile and ineffective in response to current challenges, the trend of globalization and the demand for global governance approaches have already passed the point of no return. The future of global governance will be mainly shaped by the following five factors: individual empowerment, increasing awareness of human security, institutional complexity, 
international power shift and liberal world political paradigm. We draw this conclusion by applying the findings and observations from different field of studies including security studies, international political economy, global governance field and communications studies.

First, because of information technology and mass/social media, individual citizens-especially in developed countrieshave acquired much more information power than a half century ago. Individuals can attain higher awareness of situations related to national and international affairs. Compared with humans in the twentieth century, a majority of those in the twenty-first century can more easily access international security information, thanks to the Internet and media exposure. Therefore, individual citizens of the world are more likely to understand the importance and the impact of international security on their personal lives. Digital media played a major role in the Arab Spring of 2011 in Egypt and Tunisia: social networks allowed communities to unite around shared grievances and nurture transportable strategies for mobilizing against dictators (Howard and Hussain, 2011). Globalization of the new media illustrates how communities throughout the world can be mobilized for collaborative response as well signals a new trend in the intersection of new media and conventional media such as television, radio and mobile phone (Khondker, 2011). The US National Intelligence Council also identified individual issues and the decreasing influence of the state as one of the main global trends for the twenty-first century, arguing that the potential political power of individuals has significantly increased since the end of the Cold War because of the proliferation of information and transportation technologies (National Intelligence Council, 2012). This trend will strengthen the convergence between domestic and international politics, constraining state behavior (Putnam, 1988) and continue to produce many transnational actors. Considering the dramatic increase of individuals' capabilities in information gathering, analysis and political projection, the trend of individual empowerment is logically supposed to pave a wider road towards cooperative global governance, because peace is generally preferred over war by individual humans.

Second, as the trend towards "individual empowerment" continues, global society through global governance architecture will need to pay high attention to human security, which protects individual humans from fatal threats to physical safety, and human dignity, whether human-made or of natural origin. Human security is an innovative concept for security in response to horizontal (such as military, economic and political) and vertical (such as individual, state and global) threats, which traditional security concepts cannot effectively control (Grayson, 2008). The focal point of state security is too narrow to encompass the myriad threats that challenge societies today. The threat of sovereign states engaging in large-scale war is less probable today than at any time in modern history. War has not been eliminated, rather its form has shifted from sovereign versus sovereign to substate wars between differing identity groups or insurgencies against the state. Beyond war, the concept of human security is concerned with varieties of security: economic, food, health, environmental, personal, community and political security (UNDP 1994). Human security provides an excellent compatible conceptual paradigm to global governance regimes in the future, which must respond to transnational, multi-dimensional threats that a single country cannot manage. For example, a number of national security analysts have already begun to recognize environmental degradation and natural disasters such as epidemics, floods, earthquakes, poverty and droughts as national security threats similar to military disasters (King and Murray, 2001-2002).
Third, we must additionally consider "institutional complexity" (Held and Hale, 2011) as another direction for future global governance development. As the trend of individual empowerment gains more momentum, the influence of civil society is expected to grow in terms of authority and resources. Various non-state actors will not only affect their national governments' behavior more significantly, but will also engage in networks of transnational relations more actively. International institutions in global governance will likely keep expanding to "regime complex", a concept defined as "an array of partially overlapping and nonhierarchical institutions governing a particular issue area" (Raustiala and Victor, 2004).

Fourth, global governance in the future will be also be shaped by power shifts in international relations. Almost all the traditional institutions of global governance were initiated by Western countries, and their pluralistic political culture and influential civil societies have shaped the political context of global governance. States of the Global South, especially China, have improved their relative power in relation to the Global North. As a result, the voice of actors originating from the Global South is expected to become more prominent in global governance regimes and institutions traditionally dominated by a small number of the Global North states. Therefore, an increase in multilateralism will further complicate the face of global governance.

Fifth, the future of global governance is also rooted in liberal paradigms of world politics. States and non-state or transnational actors tend to be more cooperative with global governance when a liberal world order is maintained. Global governance regimes to date have evolved with liberal paradigms such as democracy, bottom-up orientations and human rights promotion. While the advancement of democratic practices in the states without strong traditions of following liberal values remain a challenge, democracy has near-universal appeal among people of every ethnic group, every religion, and every region of the world and democracy is embraced as an international norm by more states, transnational organizations and international networks (McFaul, 2004). Liberal approaches challenge the traditional concept of the state as a unified unitary actor that lacks adverse interpretation of national interest. Accordingly, even in traditional security areas, there are more spaces for international cooperation. Global security governance through intergovernmental institutions such as the UN, International Atomic Energy Agency and International Criminal Court has made considerable progresses and gained more influence. If the realist paradigm dominates national security, however, the world would have to overcome deep uncertainty and doubt about the effectiveness of global governance. As a result, global governance today and in the future will be in the face of such serious threats as US-China hegemony rivalry, US-Russia military confrontation and Middle East conflicts. Nevertheless, as long as global society retains liberal paradigms powerful enough to offset the negative effects of mutually suspicious realist paradigms, global governance will continue to generate into effective hybrid regimes that hold the potential of creating a future world that is more cooperative, sustainable and secure.

\section{References}

Abbott K and Snidal D (2010) International regulation without international government: Improving IO performance through orchestration. The Review of International Organizations; 5 (3): 315-344.

Adams S (2015) Failure to Protect: Syria and the UN Security Council. Global Center for the Responsibility to Protect, http://www.globalr2p.org/media/files/ syriapaper_final.pdf, accessed 15 October 2015. 
Annan K (2005) In Larger Freedom: Towards Development, Security, Human Rights for All. UN General Assembly, http://www.un.org/en/events/pastevents/in larger_freedom.shtml, accessed 3 October 2015.

Barkin S (2013) International Organization: Theories and Institutions. Palgrave Macmillan: New York.

Bhagwati J (2004) In Defense of Globalization. Oxford University Press: New York.

Biermann F and Pattberg P (2008) Global environmental governance: Taking stock, moving forward. Annual Review of Environment and Resources; 33, 277-294.

Biermann F and Pattberg P (2012) Global Environmental Governance Reconsidered. MIT Press: Cambridge, MA.

Carbonnier G, Brugger F and Krause J (2011) Global and local policy responses to the resource trap. Global Governance; 17, 247-264.

Coen D and Pegram T (2015) Wanted: A third generation of global governance research. Governance: An International Journal of Policy, Administration, and Institutions; 28 (4): 417-420.

Dingwerth K and Pattberg P (2006) Global governance as a perspective on world politics. Global Governance; 12 (2): 185-203.

Grayson K (2008) Human security as power/knowledge: The biopolitics of a definitional debate. Cambridge Review of International Affairs; 21 (3): 383-401.

Held D and Hale T (eds.) (2011) Editors' introduction: Mapping change in transnational governance. In: Handbook of Transnational Governance: New Institutions and Innovations. Polity Press: Cambridge, UK, pp 1-36.

Hale T, Held D and Young K (2013) Gridlock: Why Global Cooperation is Failing When We Need It Most. Polity Press: Oxford.

Howard P and Hussain M (2011) The upheavals in Egypt and Tunisia: The role of digital media. Journal of Democracy; 22 (3): 35-48.

Karns M and Mingst K (2015) International Organizations: The Politics and Processes of Global Governance. Lynne Rienner Publishers: Boulder, CO.

Khondker H (2011) Special forum on the Arab revolutions: Role of the new media in the Arab Spring. Globalizations; 8 (5): 675-679.

King G and Murray C (2001-2002) Rethinking human security. Political Science Quarterly; 116 (4): 585-610.

Lesage D and Van de Graaf T (2015) Rising Powers and Multilateral Institutions. Palgrave Macmillan: London.

Luck E (2015) R2P at ten: A new mindset for a new era? Global Governance; 21 (4): 499-504.

McFaul. (2004) Democracy promotion as a world value. The Washington Quarterly; 28 (1): 147-163.

McGrew A (2008) Globalization and global politics In: Baylis J, Smith S and Owens P (eds) The Globalization of World Politics: An Introduction to International Relations, 4th edn., Oxford University Press: New York, pp 16-33.

National Intelligence Council. (2012) Global Trends 2030: Alternative Worlds, https://globaltrends2030.files.wordpress.com/2012/11/global-trends-2030november2012.pdf, accessed 12 September 2015.
Pearson R and Seyfang G (2001) New hope or false dawn? Voluntary codes of conduct, labour regulation and social policy in a globalizing world. Global Social Policy; 1 (1): 49-78.

Putnam R (1988) Diplomacy and domestic politics: The logic of two-level games. International Organization; 42 (3): 427-460.

Raustiala K and Victor D (2004) The regime complex for plant genetic resources. International Organizations; 58, 277-309.

Shaw T (2015) From post-BRICS' decade to post-2015: Insights from global governance and comparative regionalisms. Palgrave Communications; 1 , 14004. doi: 10.1057/palcomms.2014.4.

Stephen P (2014) Rising powers, global capitalism and liberal global governance: A historical materialist account of the BRICs challenge, European Journal of International Relations; 20 (4): 912-938.

UNDP. (1994) Human development report 1994, http://hdr.undp.org/sites/default/ files/reports/255/hdr_1994_en_complete_nostats.pdf, accessed 18 September 2015.

United Nations. (2015a) Sustainable development knowledge platform, https:// sustainabledevelopment.un.org/, accessed 18 September 2015.

United Nations. (2015b) Sustainable development goals, https://sustainabledevelop ment.un.org/?page $=$ view $\& n r=181 \&$ type $=230 \&$ menu $=2059, \quad$ accessed 3 October 2015

Wright C and Rwabizambuga A (2006) Institutional pressures, corporate reputation, and voluntary codes of conduct: An examination of the Equator principles. Business and Society Review; 111 (1): 89-117.

\section{Data availability}

Data sharing not applicable to this article as no datasets were generated or analysed during the current study.

\section{Additional information}

Competing interests: The authors declare no competing financial interests.

Reprints and permission information is available at http://www.palgrave-journals.com/ pal/authors/rights_and_permissions.html

How to cite this article: Rashchupkina Y (2016) Global governance: present and future. Palgrave Communications. 2:15045 doi: 10.1057/palcomms.2015.45.

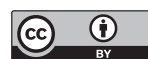

This work is licensed under a Creative Commons Attribution 4.0 International License. The images or other third party material in this article are included in the article's Creative Commons license, unless indicated otherwise in the credit line; if the material is not included under the Creative Commons license, users will need to obtain permission from the license holder to reproduce the material To view a copy of this license, visit http://creativecommons.org/licenses/by/4.0/ 